International Journal of Chronic Diseases \& Therapy (IJCDT)

ISSN 2572-7613

\title{
Mesenchymal Stem Cells Benefit Diabetes and Alzheimer's Disease
}

Li M*, Ikehara S

Editorial

Department of Stem Cell Disorders, Kansai Medical University, Hirakata City, Osaka, Japan

\section{*Corresponding Author:}

Ming Li, MD, Ph.D,

Associate Professor of Department of Stem Cell Disorders, Kansai Medical University, 2-5-1 Shinmachi, Hirakata City, Osaka 573-1010, Japan.

Tel: $81-72-804-2451$

Fax: 81-72-804-2454

E-mail: liming@hirakata.kmu.ac.jp

Received: January 10, 2015

Published: January 22, 2015

Citation: Li M, Ikehara S (2015) Mesenchymal Stem Cells Benefit Diabetes and Alzheimer's Disease. Int J Chronic Dis Ther 1(1e) 1-2. doi: http://dx.doi.org/10.19070/2572-7613-150001e

Copyright: $\mathbf{L i} \mathbf{M}^{\mathcal{O}}$ 2015. This is an open-access article distributed under the terms of the Creative Commons Attribution License, which permits unrestricted use, distribution and reproduction in any medium, provided the original author and source are credited.

Type 2 diabetes mellitus (T2DM) is characterized by chronic hyperglycemia, which induces neuron, kidney and eye dysfunction. Hyperglycemia is also a risk factor for dementia. T2DM also causes brain insulin resistance, oxidative stress and cognitive impairment. Futhermore, oxidative stress causes a complex dysregulation of cell metabolism resulting in insulin resistance and beta cell dysfunction [1]. Alzheimer's Disease (AD) is the most common form of dementia among older people worldwide, and oxidative stress is an important pathogenic factor in AD. Oxygen metabolism generates free radicals such as hydroxylradical, superoxide radical, and reactive nitrogen species, inducing ROS [2]. An imbalance between oxidant and antioxidant agents could generate oxidative stress, which damages macromolecules and disrupts the reduction/oxidation (redox) signaling [3]. Mitochondria contain many redox enzymes, and generate ROS when there are inefficiencies in oxidative phosphorylation. Mitochondrial dysfunction occurs early and has a primary role in the pathogenesis of $\mathrm{AD}$ [4]. T2DM patients show increased incidence of $\mathrm{AD}$, and one report has shown the role of insulin in that it links T2DM with AD through mitochondrial alterations, oxidative stress and glucose metabolism [5]. The insulin effect not only impacts glucose metabolism, but also has neuroprotective and neuromodulatory effects [6].

Mesenchymal stem cells (MSCs) can be isolated from bone marrow, adipose tissue, umbilical cord blood, and other tissues. MSCs have been reported to secrete factors that decrease inflammatory and immune reactions [7,8]. Human bone marrow-derived MSCs have been shown to protect human islets from pro-inflammatory cytokines [9], and to enable MSCs to differentiate into insulinproducing cells in vitro. These cells have been shown to improve hyperglycemia when transplanted into diabetic mice [10]. Human adipose tissue-derived MSCs also differentiate into glucose-sensitive insulin-producing cells, which help improve glucose levels and decrease levels of inflammatory cytokines and free fatty acids in T2DM mice [11,12]. Similarly, MSCs secrete neurotrophic factors to modulate neuroplasticity and neurogenesis [13,14]. Bone marrow-derived-MSCs were able to home in on the injured brains and increased the number of positive cells for choline acetyltransferase [15]. Autologous bone marrow- derived-MSCs have been used to transfuse into ischemic brain in clinical application [16]. In contrast, human adipose-derived MSCs have been shown to benefit neural differentiation and to help with functional improvement. When MSCs were transplanted into brains, Ach levels improved, cognitive and locomotor functions were improved in aged mice [17].

Aging associated with immune dysfunction is a risk factor for both T2DM and AD. MSC therapy has the ability to modulate the immune system and replace damaged cells, and may thus be effective in both diseases.

\section{Acknowledgment}

We would like to thank Mr. Hilary Eastwick-Field and Ms. Keiko Ando for their help in the preparation of the manuscript.

\section{References}

[1]. de la Monte SM,Wands JR (2008) Alzheimer's disease is type 3 diabetesevidence reviewed. J Diabetes Sci Technol 2(6):1101-1113.

[2]. Velayutham M, Hemann C,Zweier JL (2011) Removal of $\mathrm{H}(2) \mathrm{O}(2)$ and generation of superoxide radical: role of cytochrome $\mathrm{c}$ and NADH. Free Radic Biol Med 51(1):160-170.

[3]. Jones DP (2008) Radical-free biology of oxidative stress. Am J Physiol Cell Physiol 295(4): C849-68.

[4]. Federico A, Cardaioli E, Da Pozzo P, Formichi P, Gallus GN et al.(2012) Mitochondria, oxidative stress and neurodegeneration. J Neurol Sci 322(12): 254-262.

[5]. Barbagallo M , Dominguez LJ (2014) Type 2 diabetes mellitus and Alzheimer's disease. World J Diabetes 5(6): 889-893.

[6]. Blazquez E, Velazquez E, Hurtado-Carneiro V , Ruiz-Albusac JM (2014) Insulin in the brain: its pathophysiological implications for States related with central insulin resistance, type 2 diabetes and Alzheimer's disease. Front Endocrinol (Lausanne) 5: 161.

[7]. Aggarwal S, Pittenger MF (2005) Human mesenchymal stem cells modulate allogeneic immune cell responses. Blood 105(4): 1815-1822.

[8]. Campagnoli C, Roberts IA, Kumar S, Bennett PR, Bellantuono I et al. (2001) Identification of mesenchymal stem/progenitor cells in human firsttrimester fetal blood, liver, and bone marrow. Blood 98: 2396-402.

[9]. Yeung TY, Seeberger KL, Kin T, Adesida A, Jomha N et al. (2012) Human mesenchymal stem cells protect human islets from pro-inflammatory 
cytokines. PLoS One 7(5):e38189.

[10]. Gabr MM, Zakaria MM, Refaie AF, Ismail AM, Abou-El-Mahasen MA et al. (2013) Insulin-producing cells from adult human bone marrow mesenchymal stem cells control streptozotocin-induced diabetes in nude mice. Cell Transplant 22(1): 133-145.

[11]. Dave SD, Vanikar AV, Trivedi HL (2013) Extrinsic factors promoting in vitro differentiation of insulin-secreting cells from human adipose tissue-derived mesenchymal stem cells. Appl Biochem Biotechnol 170(4): 962-971.

[12]. Nam JS, Kang HM, Kim J, Park S, Kim H et al. (2013) Transplantation of insulin-secreting cells differentiated from human adipose tissue-derived stem cells into type 2 diabetes mice. Biochem Biophys Res Commun 443(2):775781.

[13]. Park D, Yang G, Bae DK, Lee SH, Yang YH et al. (2013) Human adipose tissue-derived mesenchymal stem cells improve cognitive function and physical activity in ageing mice. J Neurosci Res 91(5): 660-670.
[14]. Enciu AM, Nicolescu MI, Manole CG, Muresanu DF, Popescu LM et al. (2011) Neuroregeneration in neurodegenerative disorders. BMC Neurol 11: 75 .

[15]. Salem AM, Ahmed HH, Atta HM, Ghazy MA ,Aglan HA (2014) Potential of bone marrow mesenchymal stem cells in management of Alzheimer's disease in female rats. Cell Biol Int 38(12):1367-1383.

[16]. Honmou O, Houkin K, Matsunaga T, Niitsu Y, Ishiai S et al. (2011) Intravenous administration of auto serum-expanded autologous mesenchymal stem cells in stroke. Brain 134(6): 1790-807.

[17]. Ma T, Gong K, Ao Q, Yan Y, Song B et al. (2013) Intracerebral transplantation of adipose-derived mesenchymal stem cells alternatively activates microglia and ameliorates neuropathological deficits in Alzheimer's disease mice. Cell Transplant 22 (1): S113-26. 